\title{
Storability of "Jonagold" Apple Fruit under Extreme Controlled Atmosphere Conditions
}

\author{
Adriano Arriel Saquet \\ Federal Institute of Science and Education Farroupilha_Campus Panambi, Rua Erechim 860, 98280-000 Panambi, RS, Brazil
}

\begin{abstract}
In two consecutive seasons, the storage capacity of "Jonagold” apple fruit was investigated under regular air (RA) and various controlled atmosphere (CA) conditions during six months at $0 \pm 0.3^{\circ} \mathrm{C}$. The different $\mathrm{CA}$ treatment combinations were: (1) $0.5 \mathrm{kPa} \mathrm{O}_{2}+0.5 \mathrm{kPa} \mathrm{CO}_{2}$, (2) $2.0 \mathrm{kPa} \mathrm{O}_{2}+1.0 \mathrm{kPa} \mathrm{CO}_{2}$, (3) $1.0 \mathrm{kPa} \mathrm{O}_{2}+3.0 \mathrm{kPa} \mathrm{CO}_{2}$ and (4) $0.5 \mathrm{kPa} \mathrm{O}_{2}+6.0 \mathrm{kPa} \mathrm{CO}_{2}$. Ethylene production and respiration rate were evaluated at each two months storage intervals during $7 \mathrm{~d}$ shelf life at $20^{\circ} \mathrm{C}$. Fruit quality traits were analyzed immediately at the end of storage period and after $7 \mathrm{~d}$ shelf life at $20^{\circ} \mathrm{C}$. Under CA treatment, the lower the $\mathrm{O}_{2}$ and/or the higher the $\mathrm{CO}_{2}$ partial pressure, the stronger was the inhibition of the ethylene production and respiration rate of apple fruit. The $0.5 \mathrm{kPa} \mathrm{O}_{2}+6.0 \mathrm{kPa} \mathrm{CO}$ CA condition induced the strongest suppression in ethylene production and consequently lower $\mathrm{CO}_{2}$ release by apple fruit. At the end of storage period, "Jonagold” apple fruit was very tolerant to all CA conditions, and any kind of internal storage disorders was observed. The storage of “Jonagold” apple at $1.0 \mathrm{kPa} \mathrm{O}_{2}+3.0 \mathrm{kPa} \mathrm{CO}_{2}$ and $0.5 \mathrm{kPa} \mathrm{O}_{2}+6.0 \mathrm{kPa} \mathrm{CO}$ proportionated higher flesh firmness (FF), greener skin color (SC) and higher titratable acidity (TA) either immediately after storage or after $7 \mathrm{~d}$ shelf life at $20^{\circ} \mathrm{C}$. Total soluble solids were not significantly affected by CA storage conditions.
\end{abstract}

Key words: Carbon dioxide, “Jonagold” apple, controlled atmosphere conditions, fruit quality, ultra-low oxygen.

\section{Introduction}

“Jonagold” apple, a controlled cross of "Jonathan" by "Golden Delicious", is an excellent quality apple that has been widely cultivated in many countries around the world. Fruits are juicy and have a fine texture making them suitable either for the fresh market or for processing $[1,2]$.

Since the discovery and further development, the controlled atmosphere (CA) storage has been used worldwide as a modern tool to prolong significantly the storage life of fruits and vegetables [3, 4]. Apples particularly respond very positive to lowering $\mathrm{O}_{2}$ partial pressure $(p)$, which in many cases combined with increasing partial pressure of $\mathrm{CO}_{2}$ in $\mathrm{CA}$ rooms, prolonging the storage life more than three times compared to the traditional regular air (RA) storage. In addition to the lowering of temperature in RA, the lowering $p$ of $\mathrm{O}_{2}$ and increasing $p$ of $\mathrm{CO}_{2}$ reduce significantly the fruit metabolism, keeping higher

Corresponding author: Adriano Arriel Saquet, professor, research fields: postharvest biology and technology. flesh firmness (FF), titratable acidity (TA), juiciness and greener skin color (SC) in various apple cultivars [2, 5-9].

The storage performance of “Jonagold” apple fruit under CA vary depending on the region and growing season. “Jonagold” apple grown in British Columbia region is quite susceptible to flesh browning and flesh breakdown, particularly late-picked, water cored, oversized ones, and low in fruit calcium [10]. On the other hand, Lau [11] found that “Jonagold” apple fruit picked at an optimum maturity stage could be held at $1.5 \mathrm{kPa} \mathrm{O}_{2}$ at $0{ }^{\circ} \mathrm{C}$ for six months without any kind of injury symptoms. Gabioud et al. [8] stored "Jonagold” apple fruit under $1 \mathrm{kPa} \mathrm{O}$ combined with $3 \mathrm{kPa} \mathrm{CO}_{2}$ for 10 months and no occurrence of internal storage disorders was found. "Jonagold" grown in Europe has been shown to be tolerant to $p$ of $\mathrm{O}_{2}$ in $1-3 \mathrm{kPa}$ and sometimes combined with 3-5 $\mathrm{kPa} \mathrm{CO}_{2}[2,12,13]$.

The aim of this research was, therefore, to study the storage capacity of “Jonagold” apple fruit under various CA combinations, especially under hyper-low $0.5 \mathrm{kPa}$ 
$\mathrm{O}_{2}$ combined with $6.0 \mathrm{kPa} \mathrm{CO}_{2}$ in keeping fruit quality.

\section{Materials and Methods}

\subsection{Plant Materials and Seasons}

Over two consecutive seasons in 2000 and 2001, "Jonagold" apple fruit was harvested at the pre-climacteric stage, determined by starch-iodine test, FF, TA, total soluble solids (TSS) and SC. Fruit was harvested in an experimental orchard from the Competence Center for Fruit Growing Bavendorf, Ravensburg, located in South Germany. Immediately after harvest, at the laboratory, fruits were selected for maturity stage, size, SC and physical damages and/or any other defects. Each experimental treatment used at least 45 fruits in three true replicates. The replicates were made using three CA rooms with the same storage condition to get high reliability in the results.

\subsection{Storage Procedures}

Fruit were stored for six months under RA and various CA conditions at $0 \pm 0.3{ }^{\circ} \mathrm{C}$ and $7 \mathrm{~d}$ shelf life at $20^{\circ} \mathrm{C}$. For fruit shelf life measurements, a specific storage room was used to keep the temperature in the range of $20 \pm 0.3{ }^{\circ} \mathrm{C}$. The CA conditions investigated were: (1) $0.5 \mathrm{kPa} \mathrm{O}+0.5 \mathrm{kPa} \mathrm{CO}$, (2) $2.0 \mathrm{kPa} \mathrm{O}_{2}+$ $1.0 \mathrm{kPa} \mathrm{CO}_{2}$, (3) $1.0 \mathrm{kPa} \mathrm{O}+3.0 \mathrm{kPa} \mathrm{CO}$ and (4) 0.5 $\mathrm{kPa} \mathrm{O}_{2}+6.0 \mathrm{kPa} \mathrm{CO}$. Storage procedures are as described by Saquet et al. [14]. Very important to inform that three individual CA rooms were used as replicates with the same CA combination each treatment.

\subsection{Monitoring the Storage Disorders}

The monitoring of storage disorders was carried out using at least 45 fruit in three replicates for each treatment. Fruit were cut in several transversely sections to perform a detailed visual examination of the flesh.

\subsection{Respiration Rate and Ethylene Production}

For measurements of fruit respiration, expressed by the $\mathrm{CO}_{2}$ release in air at $20^{\circ} \mathrm{C}$, after each storage sampling time, four fruit per treatment in three replicates were placed inside $2.2 \mathrm{~L}$ volume sealed glass jars with continuous air stream for $7 \mathrm{~d}$ at $20{ }^{\circ} \mathrm{C}$ as described before [15]. After $24 \mathrm{~h}$ of each storage sampling time, fruit reached $20^{\circ} \mathrm{C}$ and the $\mathrm{CO}_{2}$ release was measured with an infrared gas analyser (URAS-2, Fa. Mannesmann, Düsseldorf, Germany). $\mathrm{CO}_{2}$ release was measured during $7 \mathrm{~d}$ shelf life period after every two months storage intervals.

Ethylene production of apple fruit was measured in the same glass jars samples used for $\mathrm{CO}_{2}$ release in air at $20^{\circ} \mathrm{C}$ as described before. Ethylene was analysed as follows: $2 \mathrm{~h}$ after sealing the glass jars, $1 \mathrm{~mL}$ headspace was collected and immediately injected in to a Varian gas chromatograph series 2700 with an activated aluminium oxide packed column $(0.9 \mathrm{~m})$; the injector temperature was set at $150{ }^{\circ} \mathrm{C}$ and the flame ionization detector and oven temperature at $100{ }^{\circ} \mathrm{C}$. The ethylene production of apple fruit was calculated using ethylene external standards and the results given in $\mu \mathrm{L} / \mathrm{kg} \cdot \mathrm{h}$ $\mathrm{C}_{2} \mathrm{H}_{4}[15]$.

\subsection{Changes in SC}

The color of skin surface was measured in CIE ( $L^{*}$, $\left.a^{*}, b^{*}\right)$ color space with a tri-stimulus CR-300 colorimeter (Konica Minolta Inc., Tokyo, Japan). Measurements were made in the widest and greenest part of the equatorial region of each fruit in three replicate batches of 15 fruit each. Results were expressed as CIE lab $\left(a^{*}+b^{*}\right)$ [15].

\subsection{Changes in FF}

FF was measured after skin removal with a penetrometer equipped with a $10 \mathrm{~mm}$ probe. The maximum force to insert the probe into the fruit flesh was recorded. FF was measured twice in opposite sides of fruit at the equatorial region, in three replicated batches of 15 fruit each and expressed in Newtons (N) [15].

\subsection{Measurements of TSS and TA}

For TSS and TA, fruit were cut transversely in the 
equatorial region and a disc of $10 \mathrm{~mm}$ thick was used for juice extraction. TSS in percentage was measured in the juice with a digital refractometer (Atago PR 1, Bellevue, USA). For TA analysis, an aliquot of $10 \mathrm{~mL}$ juice was diluted in $90 \mathrm{~mL}$ distilled water and the solution titrated with $0.1 \mathrm{~N} \mathrm{NaOH}$ until $\mathrm{pH}$ 8.1. TA was expressed as meq/100 $\mathrm{mL}$ [15].

\subsection{Statistical Analysis}

For all analyses investigated, at least three true replicates were used as described early in each parameter analysed. For statistical analysis, the standard deviation (SD) of replicates was calculated. The results are expressed by the means of the three true replicates \pm SD.

\section{Results and Discussion}

\subsection{Storage Disorders}

After six months of storage during the two storage seasons, "Jonagold" apple fruit did not develop any kind of storage disorders even under the extreme condition $0.5 \mathrm{kPa} \mathrm{O}_{2}+6.0 \mathrm{kPa} \mathrm{CO}_{2}$. These results confirm the tolerance of "Jonagold" apple fruit during CA storage as reported early in the $p$ of $\mathrm{O}_{2}$ below 1 $\mathrm{kPa}$ and/or combined with the $p$ of $\mathrm{CO}_{2}$ of 3-4 kPa [2, $12,13]$. However, the great impact was the very high tolerance of "Jonagold" apple fruit to the hyper-low $p$ of $\mathrm{O}_{2}\left(0.5 \mathrm{kPa} \mathrm{O}_{2}+6.0 \mathrm{kPa} \mathrm{CO}_{2}\right)$ during the full storage time.

\subsection{Ethylene Production}

Ethylene production of "Jonagold" apple fruit is shown in Fig. 1. Fruit kept under RA produced the higher rates of ethylene and reached the maximum only at the sixth month of storage. The ethylene production rate was differently inhibited according to the various $\mathrm{CA}$ conditions, and it was particularly suppressed at $1.0 \mathrm{kPaO}_{2}+3.0 \mathrm{kPa} \mathrm{CO}$, and $0.5 \mathrm{kPa}$ $\mathrm{O}_{2}+6.0 \mathrm{kPa} \mathrm{CO}_{2}$.

It is well known that increasing the $p$ of $\mathrm{CO}_{2}$ and/or lowering the $p$ of $\mathrm{O}_{2}$ during CA storage affects the ethylene biosynthesis and its action. More than 50 years ago, Burg and Thimann [16] showed that decreasing $p$ of $\mathrm{O}_{2}$ from $3 \mathrm{kPa}$ to $1 \mathrm{kPa}$ reduced the ethylene biosynthesis in apple fruit by approximately $50 \%$. A further discovery was that molecular $\mathrm{O}_{2}$ is a co-substrate of 1-aminocyclopropane-1-carboxylate (ACC) oxidase, one of the key enzyme in ethylene biosynthesis [17]. Furthermore, Gorny and Kader [18] showed that lowering the $p$ of $\mathrm{O}_{2}$ during CA storage reduced the activity of ACC synthase, another key enzyme in ethylene metabolism.

Carbon dioxide in CA storage rooms affects ethylene biosynthesis and action by different mechanisms and in various biochemical pathways. Depending on $p$ of $\mathrm{CO}_{2}$, a dual effect in ethylene metabolism can be showed. At low $p$ of $\mathrm{CO}_{2}$ as low as $0.5 \mathrm{kPa}$, ACC oxidase is activated [19], however at higher $p$ of $\mathrm{CO}_{2}$, it acts as a competitive inhibitor of ethylene action [20]. A detailed review on $\mathrm{CO}_{2}$ effects and mode of action of $\mathrm{CO}_{2}$ on ethylene metabolism is available in Ref. [21].

\subsection{Respiration Rate}

$\mathrm{CO}_{2}$ release of "Jonagold" apple fruit during storage is shown in Fig. 2. $\mathrm{CO}_{2}$ release apple fruit stored in RA was higher than all other storage conditions during the full storage time, and paralleled with the ethylene production measured at the same time. After six months of storage, apple fruit kept under $1.0 \mathrm{kPa} \mathrm{O} \mathrm{O}_{2}+3.0 \mathrm{kPa} \mathrm{CO}$ released exactly 50\% of the $\mathrm{CO}_{2}$ released by RA stored apple fruit. The respiration was markedly suppressed in fruit at 0.5 $\mathrm{kPaO}_{2}+6.0 \mathrm{kPaCO}_{2}$, releasing only $35 \%$ of the $\mathrm{CO}_{2}$ measured in RA stored apple fruit.

High $p$ of $\mathrm{CO}_{2}$ inhibits the activity of different enzymes and can uncouple the oxidative phosphorylation. As reported early by Knee [22] and Monning [23], the activity of succinate dehydrogenase is especially inhibited by high $p$ of $\mathrm{CO}_{2}$ in apple fruit. Investigation in "Bartlett" pear showed that the activity of cytochrome oxidase was also reduced by 


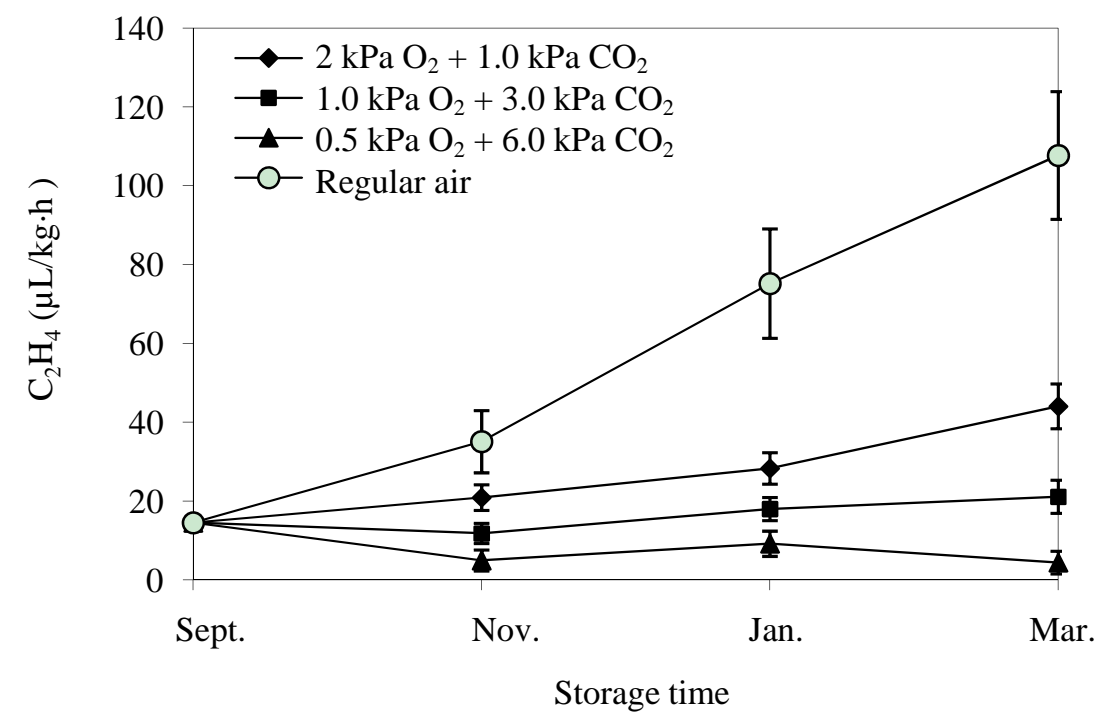

Fig. 1 Ethylene production of “Jonagold” apple fruit during $7 \mathbf{d}$ shelf life after six months storage. Vertical bars are the SD $(n=3)$.

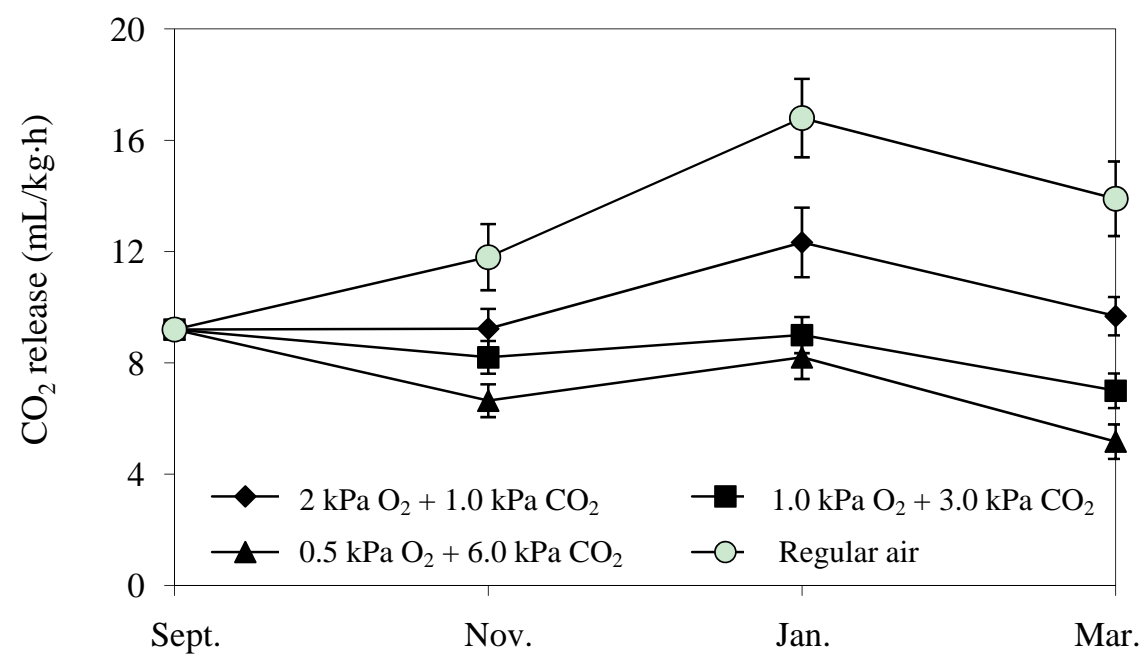

Storage time

Fig. 2 Respiration rate of “Jonagold” apple fruit during $7 \mathrm{~d}$ shelf life after six months of storage. Vertical bars indicate SD of the treatments $(n=3)$.

high $p$ of $\mathrm{CO}_{2}$ [24]. Unfortunately, in the last 20 years, the applied research has not been carried out about investigating the mode of action of CA storage on fruit metabolism, mainly on the respiratory pathways, such as the glycolysis, tricarboxylic acid cycle and the oxidative electron transport chain.

\subsection{Measurements of Quality Attributes}

Changes in FF, SC, TA and TSS after storage of
“Jonagold” apple fruit are shown in Table 1.

\subsubsection{Changes in FF}

The FF of RA stored apple fruit decreased more than $50 \%$ after six months of storage period, compared with values at harvest. On the other side, CA stored apple fruit decreased only 5\% of FF when compared with that at harvest time. Comparing the CA conditions, a slight beneficial effect of lower $p$ of $\mathrm{O}_{2}$ combined with higher $p$ of $\mathrm{CO}_{2}$ could be observed. 
Table 1 Quality attributes of “Jonagold” apple fruit immediately after six months storage (0 d) and after $7 \mathrm{~d}$ shelf life at $20{ }^{\circ} \mathrm{C}$.

\begin{tabular}{|c|c|c|c|c|c|c|c|c|}
\hline Storage condition & \multicolumn{2}{|c|}{ Flesh firmness (N) } & \multicolumn{2}{|c|}{ Skin color $\left(a^{*}+b^{*}\right)$} & \multicolumn{2}{|c|}{ Acidity (meq/100 mL) } & \multicolumn{2}{|c|}{ Total soluble solids (\%) } \\
\hline At harvest & \multicolumn{2}{|c|}{71.2} & \multicolumn{2}{|c|}{25.6} & \multicolumn{2}{|c|}{9.6} & \multicolumn{2}{|c|}{12.5} \\
\hline After shelf life & $0 \mathrm{~d}$ & $7 \mathrm{~d}$ & $0 \mathrm{~d}$ & $7 \mathrm{~d}$ & $0 \mathrm{~d}$ & $7 \mathrm{~d}$ & $0 \mathrm{~d}$ & $7 \mathrm{~d}$ \\
\hline Regular air & $38.6 \pm 4.2$ & $36.3 \pm 4.4$ & $32.7 \pm 2.3$ & $35.0 \pm 2.2$ & $5.1 \pm 0.8$ & $4.5 \pm 0.9$ & $13.0 \pm 0.5$ & $12.5 \pm 0.6$ \\
\hline $0.5 \mathrm{kPa} \mathrm{O}_{2}+0.5 \mathrm{kPa} \mathrm{CO}$ & $64.2 \pm 1.2$ & $65.3 \pm 1.3$ & $27.1 \pm 2.4$ & $33.0 \pm 2.1$ & $7.1 \pm 0.9$ & $6.0 \pm 0.8$ & $13.2 \pm 0.8$ & $13.1 \pm 0.4$ \\
\hline $2.0 \mathrm{kPa} \mathrm{O}_{2}+1.0 \mathrm{kPaCO}$ & $61.4 \pm 1.6$ & $61.0 \pm 1.5$ & $26.7 \pm 1.9$ & $30.5 \pm 2.0$ & $7.1 \pm 0.7$ & $6.8 \pm 0.9$ & $12.6 \pm 0.7$ & $12.7 \pm 0.6$ \\
\hline $1.0 \mathrm{kPa} \mathrm{O}_{2}+3.0 \mathrm{kPa} \mathrm{CO}$ & $68.3 \pm 1.9$ & $67.0 \pm 2.3$ & $25.6 \pm 2.1$ & $27.4 \pm 2.4$ & $7.4 \pm 0.7$ & $7.3 \pm 0.8$ & $13.0 \pm 0.5$ & $13.1 \pm 0.7$ \\
\hline $0.5 \mathrm{kPa} \mathrm{O}+6.0 \mathrm{kPa} \mathrm{CO}$ & $69.0 \pm 2.3$ & $68.6 \pm 2.4$ & $24.7 \pm 2.4$ & $27.3 \pm 1.9$ & $7.9 \pm 0.9$ & $7.6 \pm 0.7$ & $13.1 \pm 0.6$ & $13.1 \pm 0.5$ \\
\hline
\end{tabular}

Results are mean $\pm \mathrm{SD}(n=3)$.

The beneficial effects of CA in keeping higher FF remained even after the $7 \mathrm{~d}$ shelf life at $20{ }^{\circ} \mathrm{C}$, indicating a positive residual effect of CA storage on this parameter. Lau et al. [11] observed that CA stored "Jonagold" apple fruit were $25 \%$ firmer than RA stored fruit. "Jonagold" apple fruit stored at $0{ }^{\circ} \mathrm{C}$ under $\mathrm{CA}$ at $1.5 \mathrm{kPa} \mathrm{O}_{2}+1.5 \mathrm{kPa} \mathrm{CO}_{2}$ for six months maintained higher FF than the RA fruit [25].

During postharvest storage, apple fruit softens and its texture changes noticeably, affecting fruit quality. These changes are a result of degradation of the cell wall and middle lamella [26]. According to Kramer et al. [27], there is an increase in polyamine levels, which are involved in the beneficial effects of CA storage. Fruit stored under CA conditions were able to maintain FF throughout the six months storage period, and did not enter into the rapid softening phase as was also reported by Gwanpua et al. [28] with the same apple cultivar and same storage time.

\subsubsection{Changes in SC}

According to Brackmann et al. [7], the SC of apple fruit is one of the most important quality trait used by consumers to determine fruit quality and ripening stage in the market. In the present trial, it was very evident that there was positive effect of the low $p$ of $\mathrm{O}_{2}$ combined with the high $p$ of $\mathrm{CO}_{2}$ in keeping SC greener than RA stored apple fruit, including maintaining the residual effect after $7 \mathrm{~d}$ shelf life at $20{ }^{\circ} \mathrm{C}$. Wünsche and Heyn [2] investigated the main quality attributes in "Jonagold" apple fruit during RA storage, moderate CA and ultra-low $p$ of $\mathrm{O}_{2}$, and reported about a very similar behavior in SC. Degradation of chlorophylls is a regulated process and can be hastened by ethylene or retarded by CA storage $[29,30]$.

\subsubsection{Changes in TA}

TA showed a very similar trend like the changes in apple fruit SC. RA stored apple fruit consumed the organic acids earlier and faster than the CA stored apple fruit. Comparing results under $\mathrm{CA}$, it was possible to observe a synergistic effect of the combination of ultra-low $p$ of $\mathrm{O}_{2}$, lower than $1 \mathrm{kPa}$, with $p$ of $\mathrm{CO}_{2}$ of 3-6 kPa. A residual effect of CA was observed and CA stored apple fruit could keep higher TA even after $7 \mathrm{~d}$ shelf life at $20^{\circ} \mathrm{C}$. Lau [11] reported that the TA of "Jonagold" apple fruit under CA was about $47 \%$ higher than those under RA conditions. In a further trial, Girard and Lau [25] verified the positive effect of CA in keeping higher TA in “Jonagold” apple fruit. Recently, Wünsche and Heyn [2] confirmed the beneficial effect of CA on keeping higher TA in "Jonagold" apple fruit under very similar CA conditions after six months of storage.

\subsubsection{Changes in TSS}

TSS in fruit juice of "Jonagold" apple fruit did not show significant changes after six months of storage. This behavior is often observed, mainly during CA storage of various apple cultivars, such as "Gala" [6], "Jonagold” [2, 25], "Pink Lady" [7] and "Honeycrisp" [9]. It is well known that during storage period, organic acids are consumed earlier and faster by cell respiration than sugars [5]. According to Brackmann 
and Saquet [6], the respiration begins to use sugars only after an accentuated breakdown of organic acids during storage of apples. In case of "Jonagold" apple fruit in this study, six months of CA storage was not enough to begin a significant consumption of sugars by respiration.

\section{Conclusions}

"Jonagold" apple was stored for six months under the extreme condition under $0.5 \mathrm{kPa} \mathrm{O}_{2}+6.0 \mathrm{kPa} \mathrm{CO}_{2}$ without occurrence of any physiological disorders. The lower the $p$ of $\mathrm{O}_{2}$ and/or the higher the $p$ of $\mathrm{CO}_{2}$, the stronger was the suppression in ethylene production and $\mathrm{CO}_{2}$ release by "Jonagold" apple fruit. The lower the $p$ of $\mathrm{O}_{2}$ and/or the higher the $p$ of $\mathrm{CO}_{2}$, the higher FF, TA and green SC of "Jonagold" apple fruit immediately after storage. The quality maintenance of "Jonagold" apple fruit under $1 \mathrm{kPa} \mathrm{O}$ $+3 \mathrm{kPa} \mathrm{CO}$ was not different from that at $0.5 \mathrm{kPa} \mathrm{O}_{2}$ + $6.0 \mathrm{kPa} \mathrm{CO}_{2}$ after six months storage period. A positive residual effect of controlled atmospheres in keeping better FF, SC and TA after $7 \mathrm{~d}$ shelf life was observed.

\section{References}

[1] Brown, S. K. 1997. "Varieties of Commercial Interest: 'Jonagold'." New York's Food and Life Sciences Bulletin No. 150, New York State Agricultural Experiment Station. Accessed January, 2017. https://ecommons.cornell.edu/bitstream/handle/1813/521 4/FLS-150.pdf?sequence $=1$.

[2] Wünsche, J. N., and Heyn, C. S. 2015. "Consumer Responses to Fruit Quality of 'Jonagold' Apples Treated with Postharvest Application of 1-Methylcyclopropene (1-MCP) under Air and Controlled Atmosphere Storage Conditions.” Europ. J. Hort. Sci. 80 (1): 3-10.

[3] Smock, R. M. 1979. "Controlled Atmosphere Storage of Fruits.” Hort. Rev. 1: 301-36.

[4] Thompson, A. K. 2010. Controlled Atmosphere Storage of Fruits and Vegetables, 2nd ed.. Oxfordshire: CABI Publishing.

[5] Streif, J. 1992. "Harvest, Storage and Processing." In Lucas' Introduction to Fruit Growing, edited by Winter, F., Janssen, H., and Kennel, W. Stuttgart: Eugen Ulmer Publishing, 304-37. (in German)

[6] Brackmann, A., and Saquet, A. A. 1995. "Effect of
Controlled Atmosphere Conditions on the Occurrence of Internal Breakdown in 'Fuji' Apple.” Sci. Agric. 52: 263-7. (in Portuguese)

[7] Brackmann, A., Guarienti, A. J., Saquet, A. A., Giehl, R., and Sestari, I. 2005. "Controlled Atmosphere Storage Conditions for 'Pink Lady' Apples.” Ciência Rural 35: 504-9.

[8] Gabioud, S., Höhn, E., Gasser, F., Baumgartner, D., Naunheim, W., and Eppler, T. 2007. "Cold Storage Plus 1-MCP as Replacement for the CA Storage?” Schweiz. Z. für Obst- und Weinbau 15: 1-10. (in German)

[9] Watkins, C. B., and Nock, J. F. 2012. "Controlled Atmosphere Storage of 'Honeycrisp' Apples.” HortScience 47 (7): 886-92.

[10] Lau, O. L. 1986. "Dessert Quality and Storability of 'Jonagold’ Apples.” Postharvest Pomol. News. 4 (3): 1-4.

[11] Lau, O. L. 1988. "Harvest Indices, Dessert Quality and Storability of 'Jonagold' Apples in Air and Controlled Atmosphere Storage.” J. Am. Soc. Hort. Sci. 113: 564-9.

[12] Stow, J. R. 1987. "Storage of 'Jonagold' Apples.” Sci. Hort. 31: 245-51.

[13] Konopacka, D., and Plocharski, W. J. 2004. "Effect of Storage Conditions on the Relationship between Apple Firmness and Texture Acceptability.” Postharvest Biol. Technol. 32 (2): 205-11.

[14] Saquet, A. A., Streif, J., and Bangerth, F. 2000. "Changes in ATP, ADP and Pyridine Nucleotide Levels Related to the Incidence of Physiological Disorders in 'Conference' Pears and 'Jonagold' Apples during Controlled Atmosphere Storage.” J. Hort. Sci. Biotechnol. 75 (2): 243-9.

[15] Saquet, A. A. 2001. "Investigations on the Development of Physiological Disorders as well as on the Reduced Aroma Production in 'Conference' Pear and 'Jonagold' Apple under Various CA Storage Conditions.” Ph.D. thesis, University of Hohenheim, Stuttgart, Germany. (in German)

[16] Burg, S. P., and Thimann, K. V. 1959. "The Physiology of Ethylene Formation in Apples.” Proc. Nat. Acad. Sci. USA 45 (3): 335-44.

[17] Yang, S. F., and Hoffman, N. E. 1984. "Ethylene Biosynthesis and Its Regulation in Higher Plants.” Ann. Rev. Plant Physiol. 35: 155-89.

[18] Gorny, J. R., and Kader, A. A. 1996. "Regulation of Ethylene Biosynthesis in Climacteric Apple Fruit by Elevated $\mathrm{CO}_{2}$ and Reduced $\mathrm{O}_{2}$ Atmospheres.” Postharvest Biol. Technol. 9 (3): 311-23.

[19] Dong, J. G., Fernandez-Maculet, J. C., and Yang, S. F. 1992. "Purification and Characterization of 1-Aminocyclopropane-1-Carboxylate Oxidase from Apple Fruit." Proc. Nat. Acad. Sci. USA 89 (20): 9789-93. 
[20] Burg, S. P., and Burg, E. A. 1967. "Molecular Requirements for the Biological Activity of Ethylene." Plant Physiol. 42 (1): 144-52.

[21] Pech, J. C., Purgatto, E., Bouzayen, M., and Latché, A. 2012. "Ethylene and Fruit Ripening.” In Annual Plant Reviews: The Plant Hormone Ethylene, edited by McManus, M. T. Vol. 44. Oxford, UK: Wiley-Blackwell.

[22] Knee, M. 1973. "Effects of Controlled Atmosphere Storage on Respiratory Metabolism of Apple Fruit Tissue.” J. Sci. Food Agric. 24 (10): 1289-98.

[23] Monning, A. 1983. "Mitochondrial Respiration Activity of Cox Orange and Alexander Lucas Fruits after Treatment with High $\mathrm{CO}_{2}$ and Low $\mathrm{O}_{2}$ Concentrations.” Ph.D. thesis, Universität Bonn. (in German)

[24] Lange, D. L. 1997. "High $\mathrm{CO}_{2}$ Effects on Pear Fruit Respiratory Metabolism.” In Proceedings of the Seventh International Controlled Atmosphere Research Conference, 264-9.

[25] Girard, B., and Lau, O. L. 1995. "Effect of Maturity and Storage on Quality and Volatile Production of 'Jonagold' Apples.” Food Res. Int. 28 (5): 465-71.

[26] Mann, H. S., Alton, J. J., Kim, S. H., and Tong, C. B. S.
2008. "Differential Expression of Cell-Wall-Modifying Genes and Novel cDNAs in Apple Fruit during Storage." J. Am. Soc. Hort. Sci. 133 (1): 152-7.

[27] Kramer, G. F., Wang, C. Y., and Conway, W. S. 1989. "Correlation of Reduced Softening and Increased Polyamine Levels during Low-Oxygen Storage of 'McIntosh' Apples.” J. Am. Soc. Hort. Sci. 114 (6): 942-6.

[28] Gwanpua, S. G., Van Buggenhout, S., Verlinden, B. E., Christiaens, S., Shpigelman, A., Vicent, V., Kermani, Z. J., Nicolai, B. M., Hendrickx, M., and Geeraerd, A. 2014. "Pectin Modifications and the Role of Pectin-Degrading Enzymes during Postharvest Softening of 'Jonagold' Apples.” Food Chem. 158: 283-91.

[29] Yamauchi, N., and Watada, A. E. 1993. "Pigments Changes in Parsley Leaves during Storage in Controlled or in Ethylene Containing Atmosphere.” J. Food Sci. 58 (3): 616-8.

[30] Yamauchi, N., and Watada, A. E. 1998. "Chlorophyll and Xanthophyll Changes in Broccoli Florets Stored under Elevated $\mathrm{CO}_{2}$ or Ethylene Containing Atmosphere.” HortScience 33 (1): 114-7. 